\title{
Effects of Ecohydraulic Bank Stabilization Structures on Bank Stability and Macroinvertebrate Community in Surabaya River
}

\author{
Daru Setyo Rini ${ }^{1}$, Endang Arisoesilaningsih ${ }^{2}$, Donny Harisuseno ${ }^{3}$, Soemarno ${ }^{4}$ \\ ${ }^{1}$ Doctoral Program in Environmental Studies, Post-Graduate Program, University of Brawijaya Malang \\ ${ }^{2}$ Department of Biology, Faculty of Mathematics and Natural Sciences, University of Brawijaya, Malang, Indonesia \\ ${ }^{3}$ Department of Hydraulic Engineering, Faculty of Civil Engineering, University of Brawijaya, Malang, Indonesia \\ ${ }^{4}$ Department of Soil Science, Faculty of Agriculture, University of Brawijaya, Malang, Indonesia
}

\begin{abstract}
There were 18 accelerated erosion sites identified along $7 \mathrm{~km}$ of Surabaya River Fishery Sanctuary Area. A model of ecohydraulic bank stabilization was applied to reduce bank erosion in Surabaya River at Gresik Regency Indonesia. The model is combination of reprofiled and revegetated bank with rock toe reinforcement [1] and addition of log groynes [2]. Various native plant species were planted and naturally grown to establish multi-strata littoral vegetation structure. This study assessed effects of ecohydraulic bank stabilization on bank morphology, near bank velocity and littoral macroinvertebrate community during September 2014 to August 2016. The study found that rock toe enforcement, log groynes and reprofiled bank slope could stabilized the eroded bank, and littoral vegetation formation reduced near bank velocity at restored sites. There were 31 families of macroinvertebrate found in Surabaya River with high abundance of moderately pollution sensitive taxa Atyidae and pollution tolerant taxa Corixidae, Chironomidae and Tubificidae. The taxa richness, diversity index and abundance of sensitive and moderately sensitive macroinvertebrate group were increased after application of ecohydraulic bank stabilization at restored area. The results shown that ecohydraulic bank stabilization structure provides multi-benefits in improving bank stabilization against erosion and providing new micro-habitats for biotic community.
\end{abstract}

Keywords: ecohydraulic bank stabilization, macroinvertebrates, riparian restoration

\section{INTRODUCTION}

Surabaya River Fishery Sanctuary Area is located at lower reach of Brantas River system that has 18 accelerated river bank erosion sites. Stream bank erosion is natural process that eroding banks also occurs in most stable river systems, although the erosion rate in stable river is much slower and at smaller scale than those occurs in unstable river systems. Flooding can trigger bank erosion, as well as land use and river modification. Removal of stream bank vegetation and stream straigntening works can result in accelerated rates of bank erosion. The main process of stream bank erosion involves bank scour and mass failure. Bank scour is direct removal of bank materials by physical action of flowing water that mostly dominant in smaller streams. Mass failure includes bank collapse and slumping due to unstable bank materials topple into the stream, that mostly dominant in the lower reaches of large stream that often associate with scouring of lower banks [3].

Severe bank erosion at low land rivers induces streambank retreats, bed topography

\footnotetext{
Correspondence address:

Daru Setyo Rini

Email : darurini@yahoo.com

Address : Post-graduate Program, University of Brawijaya
}

changes, and water turbidity increase. Bank failure in nature occurs frequently that influenced by interaction of hydrodynamic conditions near bed velocity and non-cohesive banks in meandering and straight rivers. No bank failures occurs at bank angle smaller than critical value. The critical angle reduce with flow velocity and is higher in meandering river than in straight river at the middle and lower reaches of Yangtze river. Conventional groynes and revetment were used to mitigate erosion in Bangladesh but it did not provide expected results, that groyne modifications needs to improve its performance to stabilize bed topography at low flow and provide protection during high flood [4].

The terms 'ecohydraulics' and 'ecohydrology' imply research at interface between hydrological and ecological (biological) science, that are underlined as a cross-disciplinary research approach that represent a holistic and interdisciplinary, rather than multidiciplinary science. Ecohydraulics is rapidly developed as subdiscipline of river science with direct applications in water management and ecological restoration of degraded landscapes in river basin. Ecohydraulics connects ecological functions and hydrodynamic patterns at each spatio-temporal scale [5]. 
Ecohydraulics model used to test two riffle configurations and evaluated the role of several tailwater levels (imposed by the next downstream riffle that is not being altered) on physical habitat and morphological resilience. It shown that instituting a backwater effect downstream of the design riffle significantly increases the area of high-quality spawning habitat for chinook salmon and steelhead trout [6]. Ecohydraulic design has been tested in different applications and found to provide multibenefit as alternatives design for channel reconfiguration, gravel injection, floodplain and side channel inundation, increasing habitat complexity, and spawning habitat rehabilitation [7].

Riparian vegetation has strong influence on occurence and progress of streambed riverbank erosion. Re-establishing or maintaining native riparian vegetation will prevent erosion and preserve complex variety of in-stream and riparian habitat, thus it become recent riparian management practice in Australia. Presence of native riparian forest significantly reduce the likelihood of erosion by mass failure due to tree root hold the soils reinforcement and reduce likelihood of mass failure that maintain sability of channel cross-section. Some native tree species evolved roots that seek the deeper permanent summer water table in order to survive prolonged dry season. This root systems are particularly effective to reduce mass failure due to rooting depths are more than $5 \mathrm{~m}$ to $20 \mathrm{~m}$ [8].

Ecohydraulic bank stabilization design in Surabaya River consists of 5 components, i.e. bamboo stem and wood log barrier; rock toe reinforcement; log groynes triangles; reprofiled steep bank; and revegetated littoral bank. Various native plant species were planted to establish multi-strata littoral vegetation structure. This study aims to assess the effects of ecohydraulic bank stabilization on bank morphology, near bank velocity, water quality and littoral macroinvertebrate community at 2 restored sites (Wringinanom and Klubuk), compare to 1 reference site (Perning) and 2 unrestored sites (Penambangan and Lebaniwaras).

\section{MATERIAL AND METHOD}

A model of ecohydraulic bank stabilization was applied to reduce bank erosion in Surabaya River Gresik Regency Indonesia. There were 18 accelerated erosion sites along $11 \mathrm{~km}$ of Surabaya River. This study aims to evaluate effectivity of ecohydraulic bank protection model in improving littoral habitat before and after application. This study assessed ecological effects of ecohydraulic bank stabilization on bank morphology, near bank velocity and littoral macroinvertebrate community

\section{Data Collection}

The study area was located along $7 \mathrm{~km}$ of Surabaya River from Mlirip Mojokerto to Legundi Gresik that has been managed as Riverine Fishery Sanctuary Area since 2014. The map of study sites in Surabaya River Fishery Sanctuary at Brantas Basin is shown in Figure 1 . The application sites of ecohydraulic structure is shown in Figure 2.
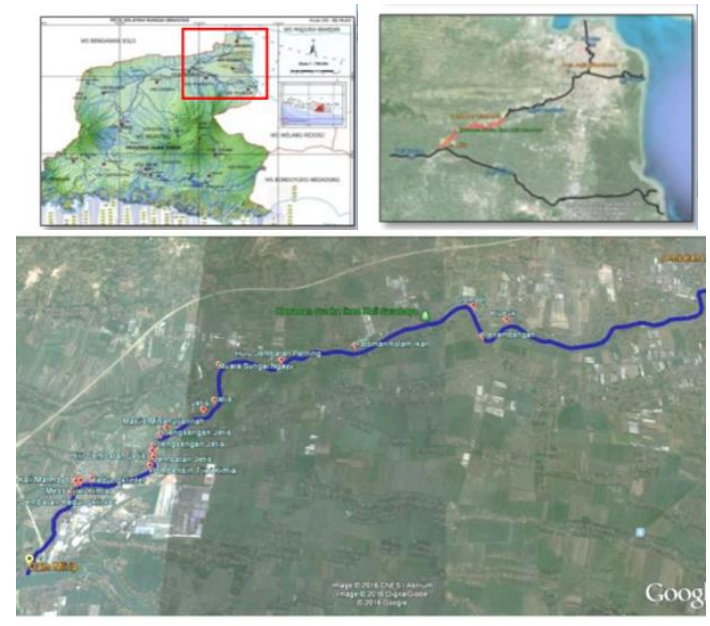

Figure 1. Map of Surabaya River in Brantas Basin (upper left); Segment of Surabaya Fishery Sanctuary in Surabaya River (upper right); Study sites in Surabaya River Fishery Sanctuary (bottom)

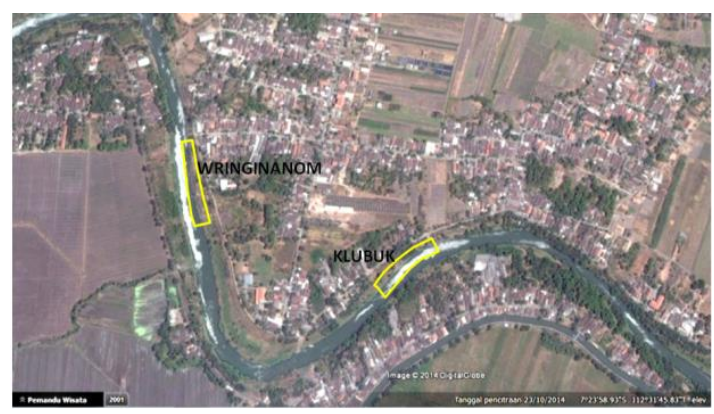

Figure 2. Application sites of ecohydraulic bank protection in Surabaya River Fishery Sanctuary

The scope of research area is limited to segment of Surabaya River at lowland elevation with current velocity less than $1 \mathrm{~m} / \mathrm{s}$ and bank eight lower than 3 meter. The research was located at 6 station, i.e. Perning, Sumberame, Wringinanom, Penambangan, Klubuk dan Lebaniwaras, that was grouped into 4 categories, 
i.e. Reference Site (Perning); Unrestored (Sumberame, Penambangan, Lebaniwaras); PreRestored (Wringinanom and Klubuk); and PostRestored (Wringinanom dan Klubuk).

The field sampling was conducted in dry season and rainy season during 2014 to 2016. The hydraulic variables measured were bank steepness, \% littoral plant cover, river width, depth, near bank velocity and water quality parameters. The secondary data of 7 year monthly average river discharge and water level was collected from Perum Jasa Tirta I Malang. The littoral macroinvertebrate samples was collected using D-net size $500 \mu \mathrm{m}$ mesh and live sorting procedures [9]. The macroinvertebrate metrics analysed were taxa richness, EPT taxa richness, Shannon diversity index, Margalef richness index, \%EPT, \%Chironomids and \%Atyidae.

The Mann-Whitney $U$ tests at $95 \%$ confidence were run to know the difference of bank steepness, near bank velocity, \% littoral vegetation cover and water quality between restored and unrestored sites, also pre-restored and post-restored sites. Multivariate Principal Components Analysis (PCA) used to analyse characteristics of each site groups and to find the most important habitat parameters which correlated with macroinvertebrate attributes.

\section{RESULT AND DISCUSSION}

\section{A. Bank Morphology at Eroded Sites}

The boat survey along $7 \mathrm{~km}$ of Surabaya River Fishery Sanctuary Area was carried out during low flow in July 2014. There were 18 accelerated eroded sites identified along $7 \mathrm{~km}$ section from Mlirip to Lebaniwaras. The length of eroded bank range from $50 \mathrm{~m}$ to $400 \mathrm{~m}$, and the bank height range from $1,5 \mathrm{~m}$ to $4 \mathrm{~m}$. The riverbank along Surabaya River is bordered with dykes and marked with riverbank points that can still be found on the dyke edges. Some native riparian vegetation species can be seen on the banks, such as variety of bamboo and grasses, shrubs, liana,herbs, and tree species. Most of the riverbanks were used for agriculture to grow corn, rice, cassava, chili and vegetables. However, in some area there were permanent houses, small factories and impermeable roads build on the riverbanks that could impair its function as floodplain area, sediment trap and wildlife habitat. The condition of bank erosion is shown in Figure 3, and the bank morphology profile at pre-restored sites is shown in Figure 4.

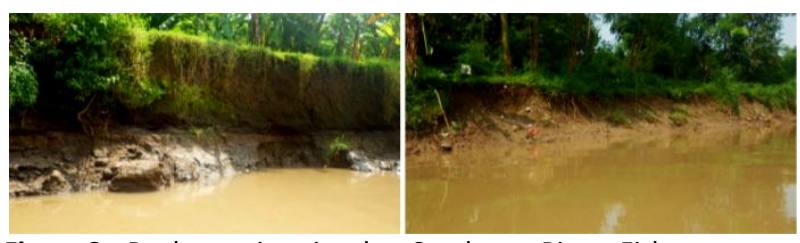

Figure 3. Bank erosion in the Surabaya River Fishery Sanctuary Area

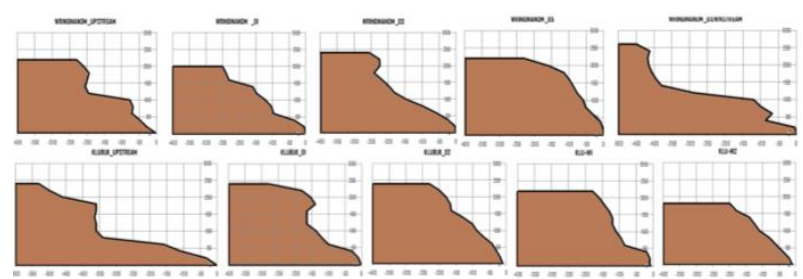

Figure 4 . Morphology of eroded bank before application of ecohydraulic bank stabilization model in Wringinanom and Klubuk

The design of ecohydraulic bank stabilization model and the condition of bank morphology at post-restored sites is shown in Figure 5.
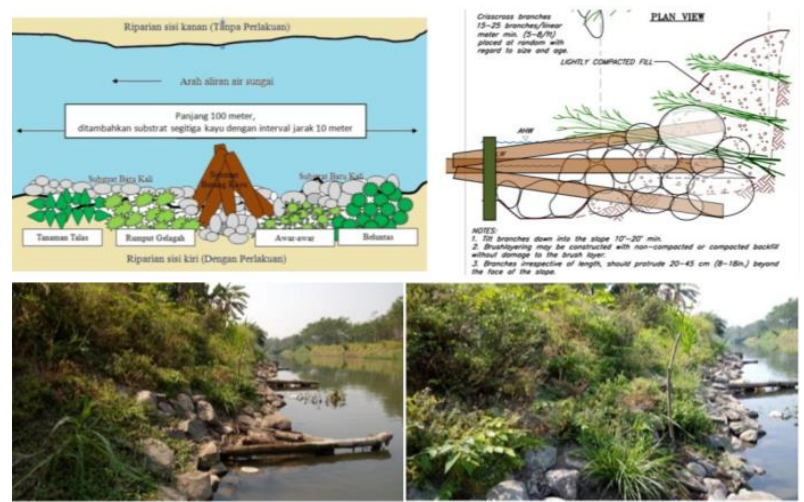

Figure 5. Design of ecohydraulic bank stabilization model in Wringinanom and Klubuk (top); Ecohyraulic Bank stabilization structure during low flow after 6 months of application (bottom)

Bankslope at Post-Restored sites become less steep due to bank reprofiling in application of ecohydraulic bank stabilization structure. The bankslope at Pre-Restored sites range was more than 45 degree, while bankslope at PostRestored sited decreased to less than 40 degree. The changes of eroded bank condition after application of ecohydraulic bank stabilization models is shown in Figure 6 . The rock toe reinforcement protects river bank base from near bed current, while the log spur triangles and littoral vegetation slowed down the near bank velocity during high flow that stabilize the eroded bank and provide new micro-habitat for river biota. 


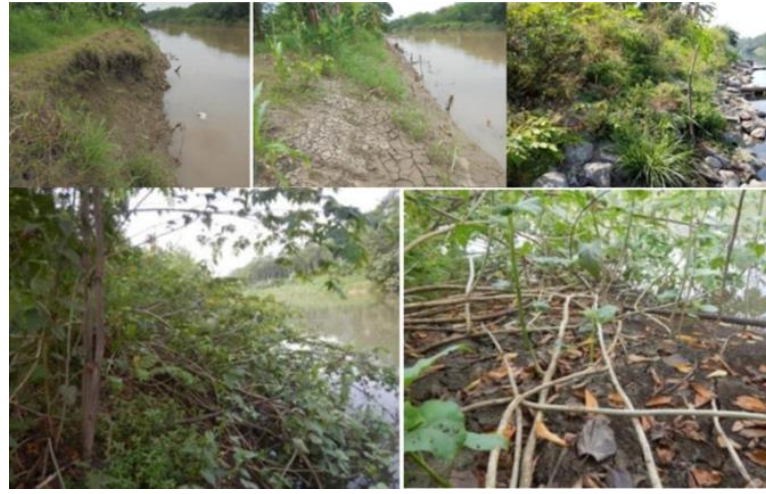

Figure 6. Change of eroded bank morphology at application sites in Wringinanom. Top left: before restoration, middle: during high flow, right: during low flow. Bottom: riparian vegetation cover after 1 year of restoration provide protection against erosion and create new macro-habitats

The results of field survey on bankslope and percentage of littoral plant cover in Surabaya River Fishery Sanctuary Area are shown as step graph in Figure 7. The bank morphology graph shown that bank slope degree at eroded sites decreased significantly and became less steep after application of ecohydraulic bank stabilization structure. The near bank velocity at post-restored sites significantly lower than both pre-restored and unrestored sites, as shown by Mann Whitney pairwise test results. The rock to enforcement and reprofiled bank slope stabilized the eroded bank. The ecohydraulic bank stabilization model succeed to maintain bank steepness to less than 40 degrees and rock toe reinforcement at bank base reduced the near bank current velocity that reduce bank erosion at restored sites. The percentage of littoral plant cover increased significantly at post-restored sites compared to pre-restored and unrestored sites. Tree species that grow well in the treatment sites that can cope with drought and floods in the floodplain area are Ipomoea aquatica, Ficus glomerata, Bambusa sp., Ficus benjamina, Hibiscus tiliaceus, Psidium guajava dan Mangifera indica.
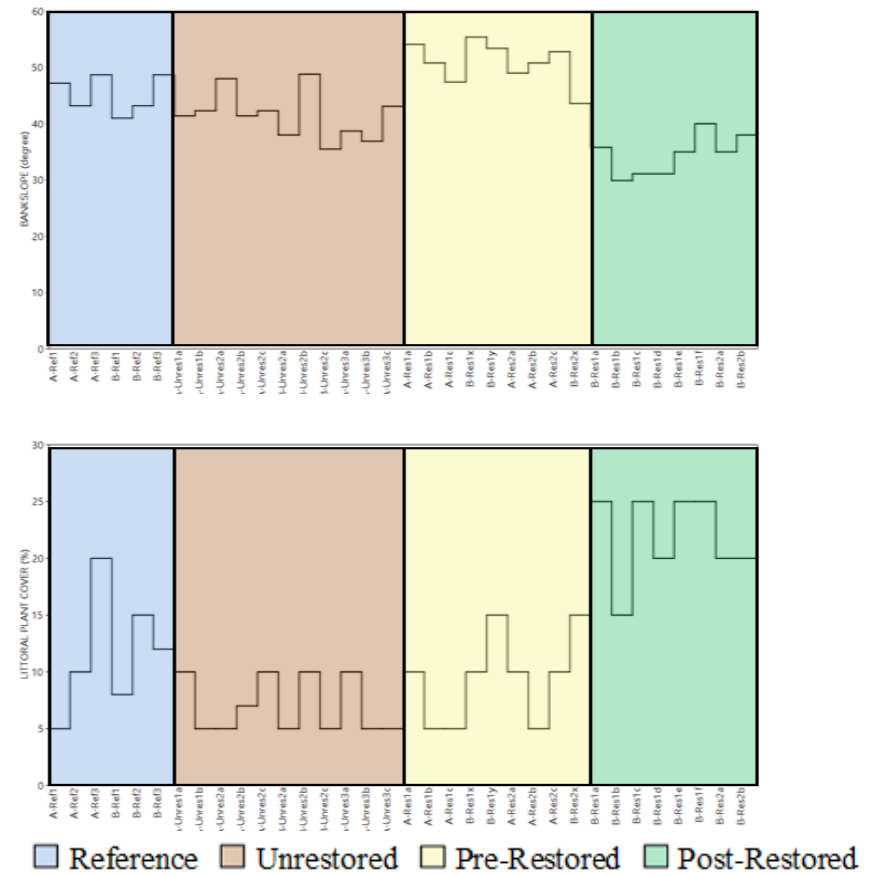

Figure 7. Bankslope and \% littoral plant cover in Surabaya River Fishery Sanctuary Area

\section{B. Hydrology of Surabaya River}

The hydrograph of Surabaya River in Perning station during 2009 - 2015 shown that wet season period occurs in December to May, while dry season period occurs in June to November (Fig.8). The highest discharge of Surabaya River in Perning was 94,2 m3/s in Januari 2013 while the lowest discharge was $20,6 \mathrm{~m} 3 / \mathrm{s}$ in October 2014. The discharge of Surabaya River is controlled by water sluice in Mlirip that control water intake to Surabaya River by diverting excess discharge from Brantas River into Porong River and Mangetan Canal. However, Surabaya River receives uncontrolled flow from Marmoyo River. The highest water elevation of Surababaya River in Perning Station was 9,5 meter above sea level in February 2015, while the lowest water elevation was 7,4 meter above sea level in July 2012, that the maximum seasonal water elevation difference was 2,1 meter that indicated the flood height in Surabaya River. Riverbank on left and right side of river channel need to be protected as flood retention zone that should be free from permanent impermeable structures to prevent more flood discharge to downstream area, to reduce sediment and pollutant loads into downstream estuarine waters. 


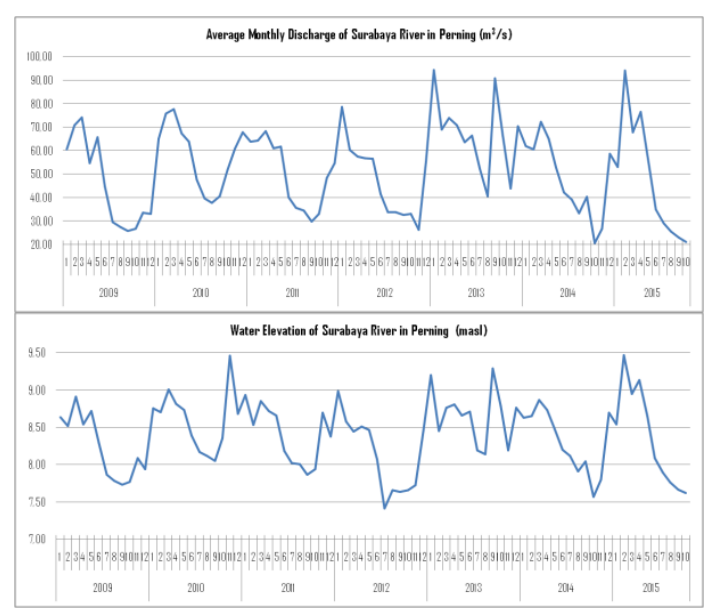

Figure 8. Average monthly discharge and water elevation of Surabaya River in Perning Station during 2009-2015 (Data Source: Perum Jasa Tirta I)

The Mann Whitney Pairwise Test at 95\% confidence shown that near-bank velocity at post-restored sites decreased significantly compare to unrestored and pre-restored sites. The ecohydraulic bank stabilization structures effectively reduce velocity near bank base and littoral river bank that reduced bank erosion and improve bank stability at restored sites. The water temperature at post-restored sites significantly different with those at unrestored and pre-restored sites. The lower temperature was due to increase of vegetation cover in littoral water and increase of shade from multi-strata vegetation on higher riverbanks. The results of hydraulic variables measured, i.e. near bank velocity and water quality parameters were shown as step graph in Figure 9.

The dissolved oxygen at post-restored sites significantly different with those at pre-restored sites. This was caused by turbulence created by rock toe reinforcement at the bank base, log spur dykes and littoral vegetation along the restored banks. The materials also provide new habitat for algae and moses to grow that increase oxygen release into water through photosyntesis by water plants grown in littoral zone. The water turbidity at post-restored sites was not different significantly with those at unrestored and prerestored sites. The water turbidity was caused by high sediment loads from upstream area due to forest degradation and land use change in the upper drainage area that could not be reduced by ecohydraulic bank stabilization at limited area with vegetation cover in littoral waters and riverbanks along restored sites.
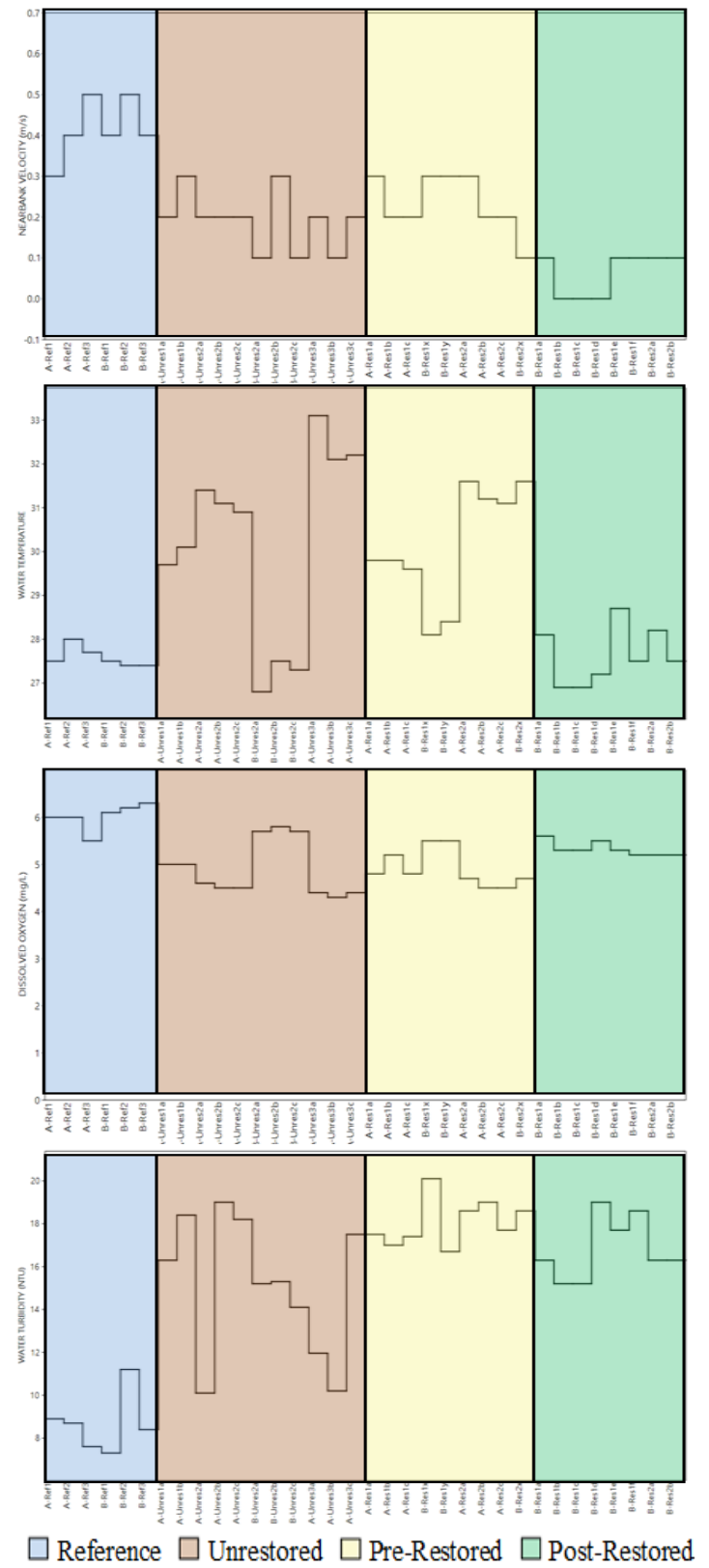

Figure 9. The steps graph of near bank velocity and water quality of Surabaya River

\section{Macroinvertebrata Community}

The results of field survey on macroinvertebrate attributes are shown in Figure 13, and the results of multivariate Principal Component Analysis (PCA) is shown in Figure 10. There were 31 families of macroinvertebrate in Surabaya River showed high abundance of moderately sensitive taxa Atyidae and pollution tolerant taxa Corixidae, Chironomidae and Tubificidae. Some of macroinvertebrate specimen are shown in Figure 11. 

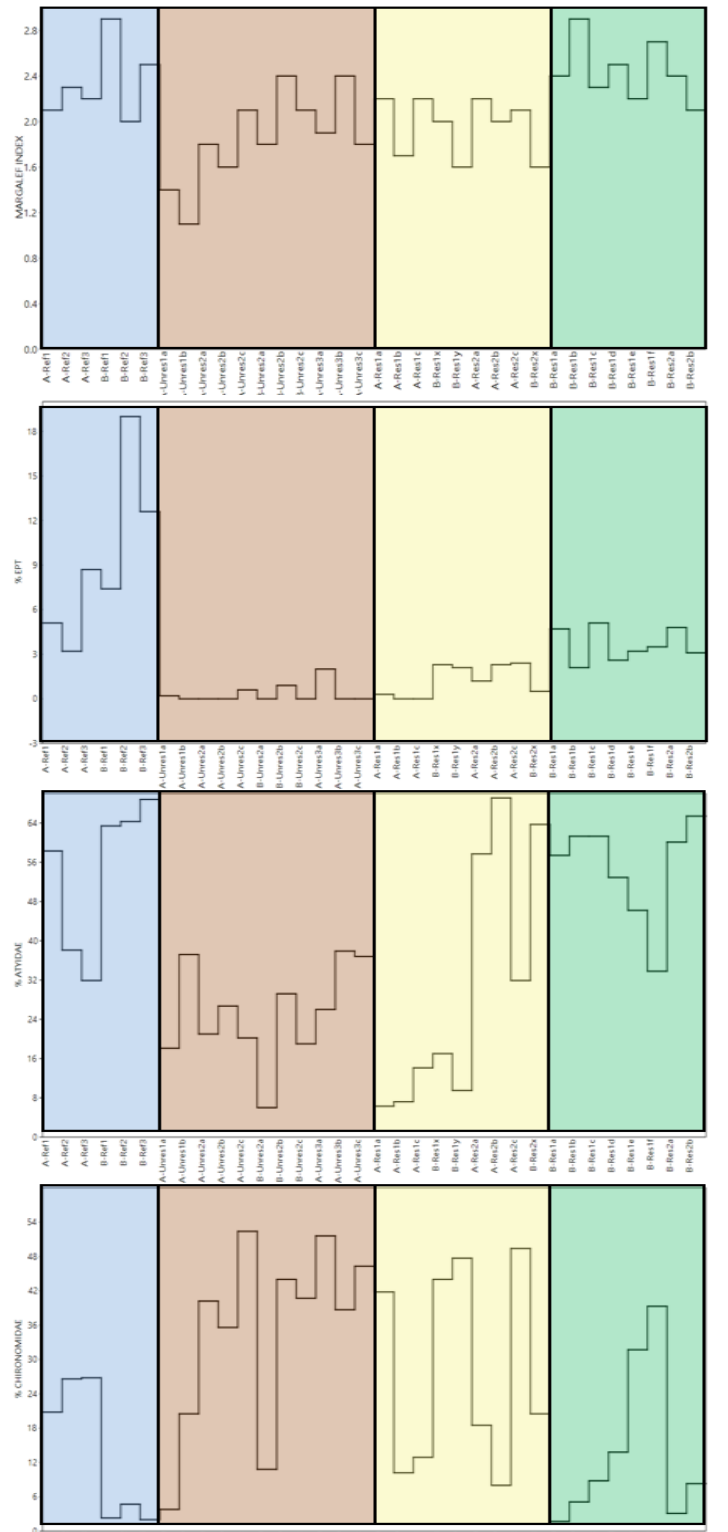

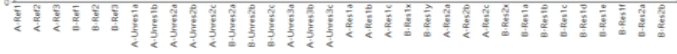

$\square$ Reference $\square$ Unrestored $\square$ Pre-Restored $\square$ Post-R

Figure 10. The steps graph of macroinvertebrate attributes in Surabaya River
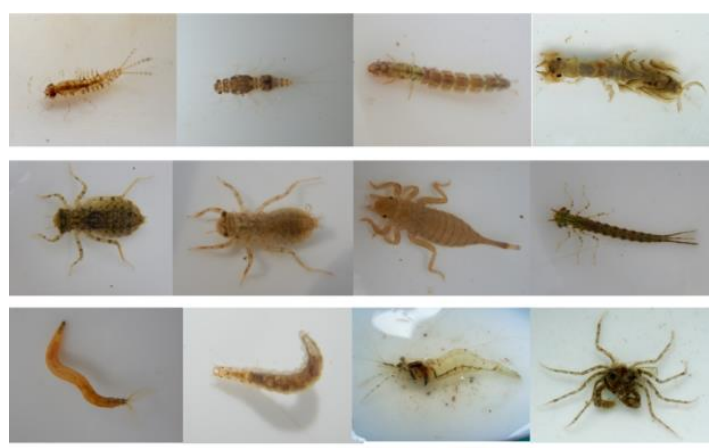

Figure 11. Macroinvertebrate specimen that were found in Surabaya River
Macroinvertebrate attributes at reference sites are better than all others sites due to its location at upstream reach contained higher dissolved oxigen and less polution sources than other sites.

The Mann Whitney U Test at ?5\% confidence shown that taxa richness and diversity index of macroinvertebrates increased significantly at post-restored sites compared to those at unrestored and pre-restored sites. The percentage of pollutant sensitive taxa EPT at post-restored sites was significantly different with those at unrestored and pre-restored sites.

The percentage of pollutant tolerant taxa Chironomidae at post-restored sites was significantly different with those at unrestored and pre-restored sites. The percentge of moderately sensitive taxa Atyidae at postrestored sites tend to increase and significantly different with those at unrestored sites. This was caused by improved bank stability and reduced bank steepness that increased percentage of vegetation cover on riverbanks thus provided more habitats for sensitive taxa and protected macroinvertebrate colony from washed away by high flow, to refuge under boulders and logs or attached on water plants roots and leaves.

The Principal Component Analysis (PCA) was applied to identify the most important hydraulic and habitat components that correlated with macroinvertebrate atributes. The results shown that there were 3 groups of sample distribution that complement with research sites groupings as shown in Figure 12.

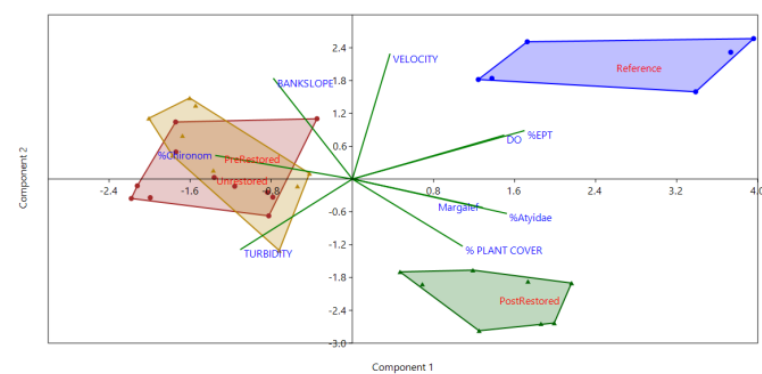

Figure 12. PCA Multivariate analysis on habitat parameters and macroinvertebrate attributes in Surabaya River

The reference group laid at upper right quadran, the post-restored group laid at lower right quadran, and the unrestored laid through pre-restored at middle left quadran. The important parameters at reference sites were near-bank velocity, Dissolved Oxigen (DO) and \%EPT. Those parameters at reference sites are 
significantly higher compared to other groups. Dissolved oxygen was strongly correlated with \% EPT. The important parameters at post-restored sites are \% littoral plant cover, Margalef's richness index and \% Atyidae. Those parameters in post-restored sites are significantly higher than other group sites.

The important parameters at unrestored and pre-restored sites are bank slope, turbidity and \% Chironomidae. This results suggest that ecohydraulic bank stabilization at post-restored sites changed the bank morfology and macroirnvertebrate community, it given effects on bank morphology improvement and supported macroinvertebrate replenishment in littoral zone of riparian habitat in Surabaya River Fishery Sanctuary Area, as indicated by increased of \% littoral plant cover, increased of Margalef's richness index and \% moderately pollution sensitive taxa Atyidae or fresh water shrimp.

\section{CONCLUSION}

The ecohydraulic bank stabilization changed eroded bank morphology due to addition of rock toe reinforcement, log spur triangles and littoral multi-strata vegetation, that decreased banksope degree and increase percentage of littoral vegetation cover. The ecohydraulic bank stabilization structures maintained bank steepness to less than 40 degrees and rock toe reinforcement at bank base reduced the near bank current velocity that reduce bank erosion at restored sites. The maximum seasonal water elevation difference was 2,1 meter as the highest flood height, that will increase near-bank velocity that induce bank erosion in Surabaya River. The ecohydraulic bank stabilization structures effectively reduce velocity near bank base and near bank surface that reduced bank erosion and improve bank stability at restored sites. The rock toe reinforcement, log spur dykes and littoral vegetation provide new habitat for algae and water plants to grow that increase oxygen release into water through photosyntesis.

The near-bank velocity, Dissolved Oxigen (DO) and \%EPT at reference sites are significantly higher compared to other groups. The hydrology and macroinvertebrate attributes at reference sites are better, due to its location at upstream reach with wider vegetated riverbanks, higher dissolved oxigen and less polution sources compared to other sites. The bank morphology, hydrology and macroinvertebrate attributes at post-restored sites improved after application of ecohydraulic bank stabilization structures through increased percentage of littoral plant cover, Margalef's richness index and percentage of moderately pollution sensitive taxa Atyidae.

\section{ACKNOWLEDGEMENT}

I thank to Ministry of Research, Technology and Higher Education of Indonesia that provide research grants in this dissertation research and Director of Perum Jasa Tirta that provide grants for the construction of ecohydraulic bank stabilization in Fishery Sanctuary Area of Surabaya River. I thank my promotor and copromotors in Doctoral Program of Environmental Studies at Brawijaya University for guidance and assistance in writing this manuscript and finishing my dissertation research.

\section{REFERENCES}

[1]. Brisbane City Council, 2000. Natural channel design guidelines. Brisbane. Australia (Book)

[2]. McCullah, John and Donald Gray. 2005, Environmentally Sensitive Channel and Bank Protection Measures. NCHRP Report No.544. Salix Applied Earthcare Redding. California (Chapter in a Book)

[3]. Yu, Ming-hui, Wei Hong-yan, and Wu Songbai, Experimental study on the bank erosion and interaction with near-bank bed evolution due to fluvial hydraulic force, International Journal of Sediment Research 30 p.81-89 (Article in Journal)

[4]. Pizzuto, J. E., \& Meckelnburg, T. S. (1989). Evaluation of a linear bank erosion equation. Water Resources Research WRERAO Vol.25, no.5, p 1005-1013, may 1989.11 Fig, 4 Tab, 37 Ref., Retrieved from http://search.proquest.com/docview/19272 222 ?accountid=46437 (Article in Journal)

[5]. Maddock, lan, Harby, Atle, and Kemp, Paul. 2013. Ecohydraulics : An Integrated Approach (1). Somerset, GB: WileyBlackwell, 2013. ProQuest ebrary. Web. 13 May 2016. Copyright (c) 2013. WileyBlackwell. All rights reserved. (Chapter in a Book)

[6]. Pasternack, G. B. 2008. Spawning habitat rehabilitation: advances in analysis tools. In (D.A.1078 Sear, P. DeVries, S. Greig, Eds) Salmonid spawning habitat in rivers: physical controls, 1079 biological responses, and approaches to remediation. Symposium 65, American Fisheries 1080 Society, Bethesda, MD. (Article within conference proceeding) 
[7]. Pasternack, G.B., Brown, R.A. 2011. Ecohydraulic Design of Gravel-Bed River Rehabilitation in the Lewiston Dam Reach of the Trinity River, CA. University of California Davis, CA. (Chapter in a Book)

[8]. Simon A. Pollen N., and Langendoen E., 2006. Influence of two woody riparian species on critical conditions for streambank stability; Upper Truckee River, California. JAWRA Journal of the American Water Resources, 42(1), pp.99-113 (Article in Journal)

[9]. Rini, D.S. 2013. Panduan BIOTILIK untuk Pemantauan Kesehatan Daerah Aliran Sungai. ECOTON dan Kementerian Lingkungan Hidup Republik Indonesia (Field Guide Booklet) 